\title{
Making the case for mental health expertise in crimen iniuria cases: An issue awakened by the Vicki Momberg sentence
}

\author{
Emma Charlene Lubaale* \\ $L L B-M U K, L L M \& L L D-U P$ \\ Senior Lecturer, School of Law, University of Venda
}

\begin{abstract}
SUMMARY
Fewer topics have recently divided South African discourse than the controversial sentencing of Vicki Momberg. Ultimately convicted of four counts of crimen iniuria, she was sentenced to an effective two year direct prison sentence as a first time offender, a sentence which is unprecedented as far as South African criminal law is concerned. This sentence has simultaneously been lauded as an effective deterrent for racial hatred and branded an unjust sentence indicative of selective prosecution and the unjust disparity between various judicial platforms. The better part of the criticism stems from the fact that the sentence was unjust. This state of affairs brings sharply into focus practical issues, in particular, the determination of just and proportional sentences in cases relating to crimen iniuria. Notably, to establish that a person's dignity has been impaired, two elements need to be proved. Firstly, the victim should have been aware of what the accused was doing to them. Secondly, the victim should have felt humiliated or degraded as a result of what the accused did to them. The point of departure of this paper is that the legality of the sentence in crimen iniuria is necessarily tied to the harm involved and this cannot be gauged physically, but rather, psychologically. The purpose of this article, therefore, is to underscore the role of expert evidence, in particular, expertise of mental health professionals, in translating the harm caused into quantifiable mitigating and/or aggravating factors with a view to ascertaining an appropriate sentence in terms of the established South African sentencing regime. This paper concludes that just and proportional sentences demand an in-depth evaluation of the "impairment of dignity" element in light of the requirement of fair, just and proportional sentences that satisfy the right to equality. This evaluation makes the role of mental health experts indispensable, yet, thus far, this has not been the case in most crimen iniuria proceedings.
\end{abstract}

\section{Introduction}

The crime of crimen iniuria finds its roots in common law. In terms of common law, it constitutes an act of "unlawful, intentional and serious

* Ms. Jana Milne, a former colleague and lecturer at the University of Venda, suddenly passed away while we were in the process of conceptualising the idea in this article. We had some discussions about this publication but she passed away before this article could be written. Her contribution towards the conceptualisation of some ideas advanced in this article is acknowledged. May her soul rest in peace.

How to cite: Lubaale 'Making the case for mental health expertise in crimen iniuria cases: An issue awakened by the Vicki Momberg sentence' 2019 De Jure Law Journal 433-446 http://dx.doi.org/10.17159/2225-7160/2019/v52a22 
violation of the dignity and privacy of another." ${ }^{1}$ Like any other common law offence, it has been the subject of prosecution, ${ }^{2}$ however, fewer decisions have recently sparked debate in the South African discourse than the crimen iniuria case pertaining to Vicki Momberg. Vicki Momberg, a former real estate agent, was convicted of using the "Kword" 3 against police officers and was sentenced to three years of imprisonment, one of which was suspended for three years (Momberg case). ${ }^{4}$ This sentence has been one of its kind as it is the very first in which the crime of crimen iniuria has attracted a custodial sentence. Not coincidentally, the sentence has ignited discussions and responses across sections in South Africa's society. Some have praised it, with different justifications being advanced. Notably, in handing down the decision, Magistrate Pravina Rugoonandan noted that the sentence was warranted in light of the fact that everyone has a right to dignity, which is worth protecting and respecting. ${ }^{5}$ Andrews, an academic, is of the opinion that "symbolically it sends a message that racism is not to be tolerated." $\mathrm{A}$ similar tone echoes through the words of Shaun Abrahams, the former National Director of Public Prosecutions, who observed that "[the sentence constitutes] victory for the rule of law and sends a strong message to every citizen to treat every other person with dignity and not to discriminate on the basis of race." Singing a similar chorus, Michael Masutha, the former Minister of Justice, was of the view that the strong sentence "will deter would-be hate crime perpetrators in [...] society."

1 Snyman Criminal law (2014) 469. See also S v Sharp 20021 SACR 360 (Ck) $372 \mathrm{~b}$; Burchell "Protecting dignity under common law and the Constitution: The significance of crimen iniuria1 in South African criminal law" (2014) South African Journal of Criminal Justice 250-271.

2 See e.g. decision in the following cases, van der Merwe \& Others $v$ State Appeal No: A366/10, free state High Court, Bloemfontein republic of South Africa; S v Sharp 20021 SACR 360 (Ck); S v Msoetrt 20061 SACR $560(\mathrm{~N})$; Pistorius $v$ The State (253/13) (2014) ZASCA 47.

3 The phrase "K-word" is used to disguise the word "Kaffirs." According to the Online Oxford English Dictionary, the term "Kaffir" is "used in several geographically quite disparate parts of the world, it ranges from being a racial insult considered so offensive in South Africa that its usage is now legally actionable there to being a perfectly neutral name for an ethnic group of South and mainland South-East Asia." See Online Oxford English Dictionary, https://public.oed.com/blog/word-stories-kaffir/ (accessed 2019. 07-28).

4 The full judgment in the case of $S v$ Momberg (Momberg case) remains inaccessible. However, the decision of the Court in this case has become judicial notice and has been reported on cites including: Gasa and Abdul Karrim, The murky case of Vicki Momberg and Crimen Injuria, 29 March 2018. http://www.witsjusticeproject.co.za/news-and-insights-category/themurky-case-of-vicki-momberg-and-crimen-injuria (accessed 2019-07-28).

5 Momberg case supra.

6 The Conversation, Jail time for South African woman using racist slur sets new precedent, 29 March 2018. http://theconversation.com/jail-time-forsouth-african-woman-using-racist-slur-sets-new-precedent-94179 (accessed 2019-09-28).

7 Daily Maverick, Landmark decision to jail race hatred woman, 29 March 2019 http://legalbrief.co.za/story/landmark-decision-to-jail-race-hatredwoman/ (accessed 2019-07-28).

8 Daily Maverick 
The sentence has also been welcomed by organisations including the Democratic Alliance, ${ }^{9}$ the South African Human Rights Commission ${ }^{10}$ and the Kathrada Foundation. ${ }^{11}$

Some sections of the South African society have, however, been skeptical of the sentence, raising concern that it could set a problematic precedent. Kevin Lawlor, Momberg's lawyer at some point, for one, considered the sentence unfair and unbalanced. ${ }^{12}$ Afriforum, a civil rights organisation has also expressed unease about the sentence, stating that it is a clear demonstration of inconsistences in the sentencing regime. ${ }^{13}$ Sharing the sentiments of other commentators, ${ }^{14}$ Afriforum takes the view that other individuals caught up in circumstances similar to those Momberg was entangled in were not subjected to such harsh punishment. ${ }^{15}$ This, Afriforum contends, is a demonstration of double standards and could risk undermining the public's faith in the justice system. ${ }^{16}$ Several other commentators remain critical of the sentence handed down in the Momberg case, contending that it might not only fail to stand legal scrutiny, but also, can hardly be upheld on appeal. ${ }^{17}$ Much of this controversy appears to stem from the blurriness of the seriousness of the crime of crimen iniuria. Magistrate Rugoonandan, in handing down the sentence in the Momberg case, alluded to the fact that "the crime of

9 Democratic Alliance, DA welcomes Vicki Momberg sentencing, 28 March 2018 https://www.da.org.za/2018/03/da-welcomes-vicki-mombergsentencing/ (accessed 2019-07-28)

10 South African Human Rights Commission, The Vicki Momberg case: Equality Court vs Criminal Court, 4 April 2018. https://www.sahrc.org.za/ index.php/sahrc-media/news/item/1289-the-vicki-momberg-case-equalitycourt-vs-criminal-court (accessed 2018-09-28).

11 Pitt, Momberg sentencing 'will act as a deterrent to other racists' - Kathrada foundation, News24, 29 March 2018, https://www.news24.com/SouthAfrica/ News/momberg-sentencing-will-act-as-a-deterrent-to-other-racists-kathradafoundation-20180329 (accessed 2019-07-28).

12 Pijoos, Vicki Momberg denied bail, sentenced to three years in prison for racist rant, Mail \& Guardian, 28 September 2018, https://mg.co.za/article/ 2018-03-28-vicki-momberg-sentenced-to-an-effective-2-years-in-prison-forracist-rant (accessed 2019-07-28).

13 Pijoos, Momberg's sentence confirms double standards in SA - AfriForum, News24, 28 March 2018, https://www.news24.com/SouthAfrica/News/ mombergs-sentence-confirms-double-standards-in-sa-afriforum-20180328 (accessed 2019-07-28).

14 Anderson, Vicki Momberg supporter says sentence was unfair, News24, 2 April 2018, https://www.all4women.co.za/1431189/news/south-africannews/vicki-momberg-supporter-says-sentence-unfair (accessed 2019-0728).

15 Pijoos, Momberg's sentence confirms double standards in SA - AfriForum, News24, 28 March 2018, https://www.news24.com/SouthAfrica/News/ mombergs-sentence-confirms-double-standards-in-sa-afriforum-20180328 (accessed 2019-07-28).

16 Pijoos, Momberg's sentence.

17 Davis, Analysis: Why the Vicki Momberg racism sentence deserves scrutiny, Daily Maverick, 29 March 2018, https://www.dailymaverick.co.za/article/ 2018-03-29-analysis-why-the-vicki-momberg-racism-sentence-deservesscrutiny/ (accessed 2019-07-28). 
crimen iniuria is generally not considered a serious offence", ${ }^{18}$ thus, confirming the general premise that crimen iniuria is not a serious offence. Yet, in handing down the sentence, which the Magistrate herself considered harsh, she observed that though generally considered a nonserious offence, "it depends how a particular person's dignity has been impaired." 19 Implicitly, Magistrate Rugoonandan would appear to have suggested that crimen iniuria, though generally categorised as a minor offence, could attract a harsh sentence if the dignity of a person is severely impaired.

If the extent to which the dignity of a person is impaired impacts directly on the sentence handed down, then, the manner in which the dignity of a complainant is impaired warrants proper assessment in keeping with the notions of just and proportional sentences. Notably, to establish that a person's dignity has been impaired, two elements need to be proved. Firstly, the victim should have been aware of what the accused was doing to them. ${ }^{20}$ Secondly, the victim should have felt humiliated or degraded because of what the accused did to them. ${ }^{21}$ The point of departure in this discussion is that the legality of the sentence in crimen iniuria is necessarily tied to the harm involved and this cannot be gauged physically, but rather, psychologically. This makes the testimony of those with expertise in psychology inevitable in assessing how the dignity of a person has been impaired. Yet, while much criticism and praise surrounds the Momberg case, very little has been written about the actual determination of this sentence. This article demonstrates that despite the critical role of the expertise of mental health professionals, hardly any recourse to such expertise has been made by the courts in crimen iniuria cases. It is therefore recommended that this nature of expertise becomes part of proceedings in crimen iniuria cases with a view to ensuring just and proportional sentences. To advance this argument, this article is divided into four parts. Following this introduction, the second section highlights the role of mental health expertise in cases of crimen iniuria. The third section briefly discusses selected crimen iniuria cases, demonstrating two things. First, that in all these cases, no prison sentence was handed down and secondly, that hardly any recourse was had to the expertise of mental health professionals. The fourth section draws a conclusion and makes appropriate recommendations.

Of course, Momberg's appeal against her sentence in the High Court has since been dismissed. She, however, still has the option to file for leave to appeal at the Supreme Court of Appeal. If the Supreme Court of Appeal confirms the decision, she could appeal further to the Constitutional Court. This suggests that this case is far from being settled. These and other developing issues in this case are not addressed in this

18 Capetown etc "Vicki Momberg's lawyers say prison sentence is too harsh", 11 April 2018, http://www.capetownetc.com/news/convicted-racist-vickimomberg-back-in-court/ (accessed 2019-07-28).

19 Vicki Momberg lawyers (2018).

20 Snyman 471.

21 Snyman 471. 
article. Instead, the article purely focuses on the question whether the time has come for due regard to be accorded to the expertise of mental health professionals in crimen iniuria cases with a view to ensuring just and proportional sentences.

\section{Expert evidence and the role of mental health professionals in crimen iniuria cases}

Expert evidence falls within the ambit of opinion evidence. ${ }^{22}$ Opinion evidence is generally inadmissible so expert evidence constitutes an exception to such rule. Expert evidence becomes relevant if the issue for determination before a given court is of such a nature that the opinion of an expert can help the court to arrive at an informed decision. ${ }^{23}$ The question to be asked therefore is- can the expert be of appreciable help to the court? In this regard, Allan and Meintjes submit that over and above the expert's knowledge, skill and expertise on the specific issue to be assessed by court, the expert should be able to be of appreciable help in guiding the court to arrive at decisions. ${ }^{24}$ Expert evidence is particularly critical in light of the fact that it is common knowledge that "there are subjects upon which the court is usually quite incapable of forming an opinion unassisted." 25 An expert's opinion, therefore, comes in handy because "by reason of their special knowledge and skill, they are better qualified to draw inferences than judicial officers." 26

It could be assumed that issues pertaining to the impairment of the dignity of an individual are within general knowledge of courts. However, for a technical issue such as this, to do so would be to underestimate the complexity assessment of such impairment and the expertise required in conducting such an evaluation. Lay opinion, including the opinion of the judicial officers may be inadequate since as Zeffert and Paizes aptly put it, "there is a strong tendency in practice, certainly in criminal proceedings, to regard lay opinion when received, as constituting prima facie evidence only." 27 Presently, however, the expertise of psychologists and other mental health professionals is hardly made use of in proceedings pertaining to crimen iniuria. As already alluded to, determining whether the dignity of a person has been impaired in cases of crimen iniuria, two aspects are to be proved. The first is the complainant must have knowledge of the action taken or conduct of the

\footnotetext{
22 Schwikkard et al Principles of evidence (2013) 83-103.

23 Schwikkard 83-103.

24 Allan and Meintjes-Van der Walt "Expert evidence" in Kaliski (ed.) Psycholegal assessment in South Africa (2006) 343. See also the case of Jacobs $v$ Transnet 2015 (1) SA 139 (SCA), para 15 where the Court ruled, amongst others, that "It is well established that an expert is required to assist the court $[\ldots] . "$ This means that if the court cannot receive any appreciate help form the expert then their opinion is irrelevant.

25 Zeffert and Paizes The South African law of evidence (2009) 237 and 321.

26 Zeffert and Paizes 237 and 321.

27 Zeffert and Paizes 340
} 
accused towards them (complainant). Secondly, the complainant must have felt humiliated or degraded as result of the conduct of the accused towards them (complainant). Presently, courts do not make use of expert evidence regarding the said two elements, with the cases briefly discussed below constituting a clear demonstration of such reluctance. In practice, the court assesses whether a reasonable person, caught up in circumstances similar to those the complainant was caught up, would have felt degraded or humiliated by the accused's conduct. Although unassisted, judges have relied on common sense, experience and knowledge to draw inferences and conclusions on the nature and extent of impairment of dignity caused as a result of the conduct or action of an accused in the various cases, it is contended that courts are ill-suited to draw such conclusions with a view to assuring consistence in sentencing. It is not only indicative of the underestimation of the complexity surrounding this assessment, but also, risks undermining the notions of just and proportional sentences resulting from arrival at conclusions regarding a field that requires special expertise.

The issue of impairment of dignity as noted already cannot be gauged physically, but rather, psychologically. In this regard, Snyman avers that dignity, self-esteem, self-respect and mental tranquility are at the heart of this evaluation. ${ }^{28}$ Snyman underscores that feelings such as mental tranquility and self-esteem are highly emotional concepts, with their manifestation varying from one person to another. ${ }^{29}$ From the foregoing elements, one can clearly garner that there is a psychological dimension surrounding this evaluation. This brings sharply into perspective the expertise of mental health professionals such as psychologists and psychiatrists. Questions arise whether they should have a role in such evaluation. Notably, clinical psychologists and psychiatrists, by virtue of their training, possess specialised knowledge necessary to identify and evaluate the mental, emotional and behavioural dynamics surrounding issues such as the effect of degrading and humiliating conduct on the mental state of an individual. ${ }^{30}$ This places them in good stead to evaluate and offer expert opinion on the implication of the accused's conduct for the dignity of the complainant. Their evidence becomes especially crucial in light of South Africa's history of discrimination, subjugation and racism where certain conduct and phrases need to be placed in proper context to avoid being misinterpreted and

\section{Snyman 471.}

29 Snyman 471.

30 See generally, Hamza "The roles of forensic mental health experts in the legal system: What practitioners of law may need to know" (2016), http:// www.voiceforthedefenseonline.com/story/roles-forensic-mental-healthexperts-legal-system-what-practitioners-law-may-need-know (accessed 2019-10-31); Golding "Mental health professionals and the courts: The ethics of expertise" (1990)13. International Journal of Law and Psychiatry 281-307; Muzaffar "Psychiatric evidence in criminal courts: The need for better understanding" (2011) Med Sci Law 141-145; Gordon "Crossing the Line: Daubert, Dual Roles, and the Admissibility of Forensic Mental Health Testimony" (2016) Cardozo Law Review 1345-1399. 
misunderstood. Such overall evaluation becomes critical in assessing the extent of impairment to the complainant and more generally, to a reasonable person. Yet, the expertise of these professionals has hardly featured when courts arrive at sentencing conclusions in cases of crimen iniuria. Moreover, the evidence of mental health professionals would also be relevant in advancing the accused's case particularly as it pertains to the mental state of the accused at the time of the commission of the conduct or action in issue. In this regard, such expertise could be of help to the court in drawing conclusions about the accused's mental state and ultimately, extent of liability. These and many factors pertaining to the mental state of the accused and the complainant could prove to be relevant mitigating or aggravating factors in the course of sentencing. Properly assessed by individuals with the relevant expertise, this could go a long way in ensuring that just and proportional sentences are arrived at.

Criminal justice systems could be weary of the opinion of mental health experts usurping the role of judicial officers, a fear that commentators consider a fallacy, ${ }^{31}$ with some commentators placing the expertise of mental health professionals in proper perspective. DeMatteo, for instance, submits as follows: "Our work is really about showing how psychology can be used to help courts and juries make more educated decisions." 32 Muzaffar adds, "human behavior and mental disorders are hard to fit into the categorical view of human behavior that the law follows. The task of the psychiatric expert is to marry these two philosophically different branches [without undermining the role of judicial officers to arrive at independent decisions]." 33 Arguably, the failure to understand the interface between law and psychiatry/ psychology often leads to the total exclusion of experts in the field of psychiatry and psychology. The unfortunate fact, however, is that courts, when deprived of such expertise, risk arriving at inconsistent or uninformed decisions. By placing their knowledge and expertise at the disposal of judicial officers, mental health experts help the courts to improve the assessment of the issue of impairment of dignity. The author agrees with Magistrate Rugoonandan to the effect that crimen iniuria, though generally considered a minor offence, can attract harsh sentences if the dignity of the complainant is severely impaired. The question, however, arises, if the nature of impairment caused to the complainant impacts on the sentence handed down, isn't it about time that the process of arriving at such a conclusion is accurately and competently accounted for? Perhaps yes and this makes the evidence of mental health professionals inevitable in not only

31 Stevens and Lubaale, Revisiting the historical context surrounding the development of the ultimate issue rule to inform its future in South African law of evidence (2016) Fundamina: A Journal of Legal History 94-117.

32 As interviewed by Novotney "Helping courts and juries make educated decisions: Forensic psychologists are in hot demand for their ability to bring the science of human behavior to the judicial system" (2017) American Psychological Association 70.

33 Muzaffar 141-145. 
defending the integrity of the decision of the court but also, advancing the goal of just and equitable sentences.

\section{Overview of the nature of proceedings in selected crimen iniuria cases}

The purpose of this section is to provide an overview of selected crimen iniuria cases, with a view to assessing the manner in which the sentences were arrived at. Did the assessment of impairment of dignity of victims of this crime go beyond mere physical harm and if so, did the court accord any regard to the expertise of mental health professionals? Three cases are briefly discussed with a view to demonstrating that generally, in all these crimen iniuria cases, the courts have hardly had any recourse to the expertise of mental health expertise and this could potentially affect the proportionality of the sentence handed down. In cases where the matter is addressed from a civil law perspective, it could profoundly affect the scope and nature of order handed down regarding damages. Before engaging with these cases, it is critical to briefly discuss the tenets of just and proportional sentences in terms of South African case law.

\section{Mental health expertise as a means to guiding sentencing discretion in arriving at just and proportional sentences}

Punishment is part of criminal prosecution and it mainly plays out at the sentencing stage. In the words of Burchell, "punishment is an integral part of the concept of a crime. Without the liability to punishment, there would be no distinction between penal and non-penal laws. Thus it follows that to render any act criminal in our law, there must be some punishment affixed to the commission of the act and where no law exists affixing such punishment there is no crime in law." 34 In South Africa, common law and legislation on sentencing map out the contours and parameters of the penalties that sentencing courts may impose. The nature and scope of the sentence may be either determinate or indeterminate. The crux of the matter however is that it has to be subject to an empowering law, be it common law or legislation.

A number of principles governs the process of sentencing, one such principle being proportionality. This principle underscores the need for the punishment to fit the crime committed. ${ }^{35}$ Proportionality seeks to ensure, amongst others, the protection of society from imposition of

34 Burchell Principles of Criminal Law (2005) 99; Santoro "Crime and punishment" in Bernstein et al Political Concepts: A Critical Lexicon (2018) 65-76.

$35 S v$ Rabie 19754 SA 855 (A) at 861 A. See also 2017 decision in Sv Nakani (SS15/2015) (2017) 2 ZAWCHC 55, in which the principle espoused in the Rabie case was re-echoed. 
sentences that are not just, respect for the law and fundamental justice. ${ }^{36}$ The Constitutional Court has observed in the case of $S v$ Makwanyane that in determining if the sentence handed down is degrading, inhuman and cruel, a question that one would need to as is whether such a sentence is proportional. ${ }^{37}$ In $S v$ Dodo, the Constitutional Court identified a number of factors to be relied on in determining the proportionality of a sentence including the nature of the crime and personal circumstances of the offender. ${ }^{38}$ These factors can also be gleaned from the case of $S v$ Zinn, ${ }^{39}$ in which the Court considered the nature of the crime, society's interests and the personal circumstances of the offender in ensuring that a sentence is proportional. In the Constitutional Court's view, in the Dodo case, "to attempt to justify any period of penal incarceration, let alone imprisonment for life as in the present case, without inquiring into the proportionality between the offence and the period of imprisonment, is to ignore, if not to deny, that which lies at the very heart of human dignity." 40

To arrive at a decision on the exact sentence to hand down, judicial officers exercise profound discretion in light of the fact that different cases present unique and varying circumstances. For sentencing courts, therefore, this discretion ensures that, the sentence handed down is not only fair, but also, individualised. The individualisation of sentencing by courts can be illustrated in the decision of $S v$ Matlotlo. ${ }^{41}$ In this case, the accused was convicted and sentenced to three years of imprisonment by the Magistrate Court upon pleading guilty to the crime of shoplifting. The convict appealed against this sentence in the High Court. Bosielo J reversed the three-year sentence, substituting it with an order of rehabilitation. In addition, half of the three years term of imprisonment was suspended subject to the accused undergoing treatment. This was in light of the fact that the accused allegedly had problem of kleptomania. It can be deduced from this decision that the discretion at the disposal of judicial officers allowed for the kleptomania circumstance of the offender to be taken into account in deciding on the sentence to be handed down.

However, such wide discretion is not without challenges. Notable is the risk of inconsistencies in sentencing. The Constitutional Court has acknowledged this dilemma, observing that:

$36 R v$ Arcand [2010] AJ No 1383 (Alta CA), 52.

$37 S v$ Makwanyane 19952 SACR 1 (CC), para 94.

$38 S v$ Dodo 20011 SACR 594 (CC), para 37. The Principle in the Dodo case has found application in recent cases including a 2018 High Court decision in the case of Zamla v S (A207/2016) (2018) ZAWCHC 130, para 13.

$39 S v$ Zinn 19692 SA 537 (A) at 540G. See also S v Selebi (Judgment on sentence) (25/2009) (2010) ZAGPJHC 58, para 1.

$40 S v$ Dodo supra, para 38, referring to Prinsloo $v$ Van der Linde 19973 SA 1012 (CC), para 31.

$41 S v$ Matlotlo 20042 SACR 549 (T). On the individualisation of sentences, see also S $v$ Scheepers 20061 SACR 72 (SCA), para 11; S v Baartman 19971 SACR 304 (E); S v Mzazi 20042 SACR 549 (T). 
"imperfection inherent in criminal trials ... means that persons similarly placed may not necessarily receive similar punishment. This needs to be acknowledged. What also needs to be acknowledged is that the possibility of error will be present in any system of justice and that there cannot be perfect equality as between accused persons in the conduct and outcome of criminal trials. We have to accept these differences in the ordinary criminal cases that come before court, even to the extent that some may go to jail when others similarly placed are acquitted or receive non-custodial sentences." 42

One garners from the above dictum that it is in fact possible for offenders who are similarly positioned to receive different sentences, with such difference going as far as some offenders receiving custodial sentences while others receiving non-custodial sentences. This dilemma underscores the critical need for sentencing courts to ensure proportionality in the sentencing process. One way of advancing this is ensuring that courts are availed with all the information and expertise relevant in helping judicial officers exercise their discretion. Jameson ${ }^{43}$ has submitted, rightly so, that:

"the scant information placed before the courts may in certain circumstances lead to the imposition of wrong sentences, because the courts do not have sufficient information to exercise their sentencing discretion properly. The review and appeal tribunals emphasise that this phase is just as important as any other phase of a criminal trial, and should receive the same attention and treatment as any other phase. The courts must have sufficient information before them to exercise their sentencing discretion properly." 44

In light of the above, an issue warranting resolution is - Thus far, how have courts dealt with the element of impairment of dignity and what implication could this have on the justness and proportionality of sentences? The next subsections engage with this question by critically analysing selected cases on crimen iniuria.

\section{State $v$ van der Merwe (5 $^{45}$}

This matter was first heard by the Bloemfontein District Court. In this case, the accused persons (four university students enrolled at the University of Free State at the time) were convicted of crimen iniuria, a crime they committed while at the University of Free State. The charge against them arose from a video they recorded. The video depicted the accused persons preparing food for the victims, urinating in it, and tricking the complainants into consuming the said food. The court, however, set the record straight, making it clear that "all these were sheer acts of playful simulation." In fact, there was no urination in the food by the accused and forced ingestion of the food by the

\footnotetext{
42 State $v$ Makwanyane supra, para 54.

43 Jameson Structuring the exercising of sentencing discretion in South African criminal courts (PhD Thesis 2018 North-West University) 36.

45 State $v$ van der Merwe Appeal No.: A366/10, Free State High Court Bloemfontein, South Africa.
} 
complainants. The Court a quo found that the conduct of the accused had the effect of impairing the dignity of the complainants. The accused persons, who all pleaded guilty to the charge of crimen iniuria, were sentenced to a fine of R 20000 and in the alternative, imprisonment for a period of 12 months. In addition, they were sentenced to a period of six months, all of which were suspended subject to multiple conditions including non-commission of the crime of crimen iniuria during the period of suspension. Dissatisfied with the sentence handed down, the accused (who at the time of the appeal were appellants), appealed the decision of the District Court before the High Court of Bloemfontein. Upon considering multiple factors, including the fact that the video that formed the crux of the charge was just a simulation, the sentence handed down by the District Court was set aside and replaced with a fine of $R$ 10000. As the discussion in this article focuses on the court's assessment of the notion of impairment of dignity, the analysis here is restricted to this aspect and how the court dealt with it. In demonstrating how impairing the conduct of the appellants were, recourse can be had to some rulings by the appellate court. The court, noted, for example, that:

"by secretly video-taping the urination scene without the knowledge and consent of the complainants the appellants betrayed the complainants in a big way. It was precisely the secrecy around the urination scene, which made the black playmates of the appellants to feel very badly betrayed. [...] Such ignominious treatment of one by another has all the criminal hallmarks, which underscored the essence of the crime of iniuria. Everyone is entitled, as a matter of right, to freedom from such contumelious treatment." 46

As consistently noted, to establish that a person's dignity has been impaired, two elements need to be proved. Firstly, that the victim was aware of what the accused was doing to them and secondly, that the victim felt humiliated or degraded because of what the accused did to them. As has been argued, feelings of humiliation and being degraded cannot be gauged physically, but rather, psychologically. The court also underscored the psychological angle to the crime of crime iniuria in $S v S$, with Marais J observing that "in the case of crimen injuria, otherwise than in the case of defamation, we are more concerned with the emotional values of words than with their intellectual connotations; the dubious or inadequate nature of the latter rarely affects the impact of the former." 47 Yet, one garners from the ruling in the van de Merwe case that the Court's decision on this issue was based on a general analysis by the presiding judge. Throughout the judgment, no reference, whatsoever was made to the expertise of mental health professionals, thus begging the question: could this have had implications for the courts' analysis and ultimately the sentence handed down? If so, can such a sentence be considered just and proportional to the crime? Arguably not.

46 State $v$ van der Merwe supra, para 43

47 S v S 1964 (3) SA 319 (T). 


\section{Ryan v Rodwin Petrus ${ }^{48}$}

This matter was before the High Court of the Eastern Cape. It involved Mrs. Ryan, who though staunchly religious, did not consider adultery sinful from a religious point of view. Because of this, she got involved in an adulterous affair with Vernon Petrus. On 24 December 2005, while Mrs. Ryan was in the company of Mr Vernon Petrus, Rodwin Petrus (a son to Mr. Vernon Petrus) uttered the following words to her: "Jou teef. Jy is " $n$ naaier. Jy naai saam met my pa en jy en my pa maak van my ma " $n$ poes. Jou kaffir, jy is " $n$ hoer." Aggrieved by these utterances, Mrs. Ryan instituted proceedings against Mr. Rodwin. The Court treated the matter before it as crimen iniuiria. The court took into account the evidence of Mrs. Ryan (the plaintiff/appellant) to the effect that "she had been deeply hurt and humiliated by the insults hurled at her. She stated that the fact that she was involved in an adulterous affair did not give defendant license to speak to her in such a manner. Her dignity, she said, had been impaired." In assessing whether or not the dignity of Mrs. Ryan had been impaired, the Court observed that:

“the use of the word 'hoer' or 'whore' also clearly constitutes an unlawful aggression upon appellant's dignity. "Whore" is defined in the Concise Oxford English Dictionary as meaning "prostitute" and "prostitute" is defined in turn as meaning "a person, typically a woman, who engages in sexual activity for payment". In my view, to call any woman, who is not a prostitute, a whore, regardless of whether or not that woman is conducting an adulterous affair, is, absent any innocuous context, to degrade and humiliate her." 49

The Court added, "in all the circumstances, [the] plaintiff has established that her dignity has been impaired. She is accordingly entitled to an award of damages to compensate her for the hurt and humiliation suffered by her." Thus, having had regard to multiple circumstances including the appellant's testimony, previous court decisions and the court's own analysis of the humiliating nature of the defendant's utterances, the court found that the dignity of the appellant had been impaired. Accordingly, the court ordered that the defendant pay R 15000 to the plaintiff in damages. Just like the Van der Merwe case above, it is apparent in the Ryan case that the court heavily relied on the appellant's own testimony and its own analysis to determine the impairment of dignity. Human J rightly ruled in $S v$ Jana, ${ }^{50}$ that "the concepts of selfrespect, mental tranquility and privacy are judged both objectively and subjectively in that it depends upon the particular person and the circumstances whether it can be said that his dignitas has in fact been impaired." Human J evidently took cognisance of the psychological dimension that the analysis of the crime of crimen iniuria takes. Yet, in all cases of crimen iniuria, including the Ryan case, recourse was not made to the expertise of experts in this field.

48 Ryan v Rodwin Petrus, Case No: CA 165/2008, in the High Court of South Africa (Eastern Cape, Grahamstown.

49 Ryan $v$ Rodwin Petrus supra, 8.

50 Sv Jana 1981 (1) SA 671 (TPD) 675 A-B. 
Reference may also be made to the decision in the case of State $v$ Molapo. ${ }^{51}$ This case was also in respect of the crime of crimen iniuria. It was before the High Court of the Orange Free State. In setting aside the crimen iniuria conviction by the court a quo, the Court ruled, amongst others, that it remained unclear "whether the complainant's dignity was indeed impaired." 52 Clarity on this issue would arguably have required evidence from multiple sources, most notably, experts in mental health given the nature of assessment to be conducted i.e. issues of self-respect and mental tranquility. Yet, the record suggests that in arriving at this decision, the court merely drew inference from the general set of facts before it and the testimonies of the various witnesses.

Cases are inexhaustible. This brief examination of cases at random leads to a few conclusions. The first being that in cases prior to the Momberg case, no offender was sentenced to a custodial sentence. Secondly, even when the presiding officers, in all the cases including the Momberg case, stressed the issue of impairment of the complainants' dignity, at no point did the prosecution and the courts have recourse to the expertise of mental health professionals, who as consistently argued in this case, are better placed to conduct an assessment on feeling of humiliation on the part of the complainant in crimen iniuria cases. The fact that prior to the Momberg case, none of the crimen iniuria convictions resulted into a custodial sentence, causes one to take a step back and to ponder? Could it be that the nature and scope of impairment of dignity in the Momberg case was more severe than that in previous cases? Assuming that this is the position, on what basis was that conclusion arrived at? Of course, when sentencing, multiple factors are taken into account and it cannot merely boil down to issues of scope and nature of impairment of the dignity of the complainant. Nonetheless, in these cases, issues of impairment of dignity play a key role in assessing the nature and gravity of the crime and ultimately, the sentence handed down. It follows logically then that if impairment of dignity is an issue that is to be gauged psychologically, and then such assessment needs to be appropriately done. Experts in the field of psychology would play a crucial role in such assessment and it is about time that crimen iniuria decisions to reflect such expertise.

\section{Conclusion}

The purpose of this article was to demonstrate the role of expert evidence, in particular, expertise of mental health professionals in crimen iniuria cases. The paper opened with a brief discussion on the controversy surrounding the recent sentence against Momberg to a custodial sentence. The sentence handed down against Momberg has been criticised by some as unfair and a demonstration of courts'

51 State $v$ Molapo Review No: 213/2006 In the High Court of South Africa (Orange Free State Provincial Division).

52 State $v$ Molapo supra, para 14. 
inconsistency in the sentencing regime of South Africa as it pertains to crimen iniuria cases. As the crime of crimen iniuria revolves around impairment of dignity, the discussion proceeded on the premise that equitable sentences can only be arrived at if courts' analysis of the element of "impairment of dignity" is appropriately conducted. A premise on which this discussion was further based was that the issue of impairment of dignity cannot be gauged physically, but rather, psychologically, thus, making the expertise of mental health professionals very pivotal. This analysis has, however, demonstrated that in all cases of crimen iniuria, including the Momberg case, courts have hardly had recourse to such expertise. Rather, presiding officers have generally conducted general analyses or relied on complainants' testimonies to draw inferences to arrive at conclusion that dignity has been impaired. In all these cases, the issues analysed by the courts have generally had a psychological dimension i.e. feelings of humiliations etc. This has made it apparent that the judges are incapable of forming an opinion on the feelings of the complainant unassisted. Nonetheless, judges have drawn inferences without receiving appreciable help from mental help experts, a practice that puts into question both the convictions and sentences handed down in these cases. Mental health expertise does not establish the guilt or innocence of the accused in crimen iniuria cases, neither does it provide definite answers regarding the sentence to be handed down. Nonetheless, the knowledge, skill and expertise of these professionals on issues of mental health place them in good stead to be of appreciable help in guiding the court to arrive at decisions on conviction and sentencing in crimen iniuria cases. 